\title{
Dietary arachidonic acid: a Janus face actor in brain and Alzheimer's disease?
}

\author{
Katleen Pinchaud $^{1}$, Katy Maguin-Gaté ${ }^{1}$ and Jean-Luc Olivier ${ }^{1,2, *}$ \\ ${ }^{1}$ Composés Alimentaires, BIofonctionnalités et NeurOTOXicité (CALBINOTOX, EA7488), Université de Lorraine, Faculté des Sciences \\ et Technologies, Boulevard des Aiguillettes, 54506 Vandoeuvre-lès-Nancy, France \\ ${ }^{2}$ Service de Biochimie-Biologie moléculaire, CHU de Nancy,24 avenue du Mal de Lattre de Tassigny, CO n 34,54018 Nancy, France
}

Received 2 March 2018 - Accepted 28 May 2018

\begin{abstract}
Arachidonic acid is the second polyunsaturated fatty acid in brain and the first one belonging to the $\omega-6$ series. Dietary intakes of arachidonic are between 50 and $300 \mathrm{mg} /$ day in western diets but they might be underestimated. Triglycerides from fat would provide similar amounts than phospholipids of lean meat. Alzheimer's disease is an age-associated degenerative disease and a critical health concern worldwide. Amyloid- $\beta$ peptide oligomers are presently recognized as the main and earliest agents of Alzheimer's disease although their neurotoxicity requires the presence of tau protein. We and others established that the arachidonic-specific cytosolic phospholipase $\mathrm{A}_{2}$ is critical for the amyloid- $\beta$ peptide oligomer neurotoxicity. Then, we showed that an arachidonic acid-rich diet increases the mouse sensitivity to the amyloid- $\beta$ peptide oligomer deleterious effect without major increase of arachidonic acid levels in brain. This suggests that dietary arachidonic acid can exert its effects in brain through peripheral modifications. Involvement of systemic sub-inflammation and gut-brain communications are discussed based on the recent literature. The various data suggest that dietary arachidonic acid should be taken into account in the design of preventive strategies against Alzheimer's disease.
\end{abstract}

Keywords: arachidonic acid / inflammation / brain / diet / Alzheimer's disease

Résumé - L'acide arachidonique alimentaire : un acteur à deux faces dans le cerveau et la maladie d'Alzheimer? L'acide arachidonique est le second acide gras polyinsaturé cérébral et le premier de la série des $\omega$-6. Les apports alimentaires d'acide arachidonique varient entre 50 et $300 \mathrm{mg} / \mathrm{jour}$ dans les régimes occidentaux mais pourraient être sous-estimés. Les triglycérides de la partie grasse des viandes fourniraient des quantités similaires aux phospholipides de la partie maigre. La maladie d'Alzheimer est une maladie neurodégénérative associée à l'âge et un problème de santé publique majeur dans le monde. Les oligomères de peptides $\beta$ amyloïde en sont désormais reconnus comme l'agent principal, bien que la présence de la protéine tau est nécessaire à leur action. Avec d'autres auteurs, nous avons établi que la phospholipase $\mathrm{A}_{2}$ cytosolique, spécifique de l'acide arachidonique, assure les effets neurotoxiques des oligomères de peptide $\beta$ amylö̈de. Nous avons ensuite montré qu'un régime riche en acide arachidonique augmente la sensibilité des souris aux effets de ces oligomères, sans augmentation majeure de ses niveaux cérébraux. Ceci suggère que cet acide gras peut agir sur le cerveau par des effets périphériques comme une sub-inflammation dont le rôle dans la relation intestin-cerveau est discutée dans la littérature. Les apports alimentaires d'acide arachidonique devrait être intégrés dans la prévention de la maladie d'Alzheimer.

Mots clés : acide arachidonique / inflammation / cerveau / régime alimentaire / maladie d'Alzheimer

\footnotetext{
*Correspondence: jean-luc.olivier@univ-lorraine.fr, jl.olivier@chru-nancy.fr
} 


\section{Abbreviations}

$\begin{array}{ll}\text { AD } & \text { Alzheimer's disease } \\ \text { AICD } & \text { Activation-induced cell death } \\ \text { APP } & \text { Amyloid precursor protein } \\ \text { ARA } & \text { Arachidonic acid } \\ \text { A } \beta \text { peptide } & \text { Amyloid-beta peptide } \\ \text { BACE 1 } & \text { Beta-secretase 1 precursor } \\ \text { CD33 } & \text { Cluster of differentiation 33 } \\ \text { CD36 } & \text { Cluster of differentiation 36 } \\ \text { cPLA2 } & \text { Cytosolic phospholipase A2 } \\ \text { DHA } & \text { Docosahexaenoic acid } \\ \text { GFAP } & \text { Glial fibrillary acidic protein } \\ \text { LDL } & \text { Low density lipoprotein } \\ \text { LNA } & \text { Linoleic acid } \\ \text { NFT } & \text { Neurofibrillary tangles } \\ \text { PSD95 } & \text { Postsynaptic density protein } 95 \\ \text { PUFAs } & \text { Polyunsaturated fatty acids } \\ \text { SNAP25 } & \text { Synaptosomal-associated protein 25 } \\ \text { SNARE } & \text { Soluble N-éthylmaleimide-sensitive-factor at- } \\ & \text { tachment protein receptor } \\ \text { TLR } & \text { Toll-like receptor } \\ \text { TREM2 } & \text { Triggering receptor expressed on myeloid cells 2 }\end{array}$

\section{Introduction}

While the influence of docosahexaenoic acid [DHA] in Alzheimer's disease [AD] or other neurodegenerative diseases focused the interest of scientific and medical communities, few works were devoted to the role of arachidonic acid [ARA] in these diseases. However, ARA is the second polyunsaturated fatty acids [PUFA] and the main member of the $\omega-6$ series in brain, representing approximately $20 \%$ of the neuronal fatty acids. In addition, ARA is converted in various eicosanoid which are important mediators in the various phases of inflammation, having pro- or anti-inflammatory activities and is involved in synaptic transmission as retrograde messenger (Nishizaki et al., 1992) and regulator of SNARE formation (Rickman and Davletov, 2005). Furthermore, ARA is considered as an essential fatty acid at least in the maturation of brain in the pre- and post-natal periods.

It is well admitted that memory alterations are caused by synaptic dysfunctions in the AD early steps. Neuro-inflammation contributes to the $\mathrm{AD}$ early synaptic dysfunctions and the neuronal death in the late steps of the disease. Therefore, ARA is putatively involved in AD through its role in synaptic signal and in inflammatory process and regulation of its brain levels could be a target in the fight against $\mathrm{AD}$ occurrence and progression. Despite its putative role in the maintenance of brain functions, excessive dietary ARA intake could lead to higher brain incorporation and favour dysregulation of ARA mobilization and conversion into pro-inflammatory mediators. However, ARA content in western diets were poorly studied until now, which makes difficult the evaluation of their impact on $\mathrm{AD}$ risk.

We will first examine, in this review, the present knowledge about the ARA place in the current western diets. After a short overview about the AD molecular actors of AD
Table 1. Evaluation of dietary arachidonic acid intakes. Few studies evaluated ARA dietary intakes in a limited number of countries and reported a large range of values.

\begin{tabular}{ll}
\hline Sources & Range \\
\hline Jonnalagadda et al., 1995 & $100 \mathrm{mg} /$ day \\
Mann et al., 1995 & $<150 \mathrm{mg} /$ day \\
Tokudome et al., 1999 & $139-168 \mathrm{mg} /$ day \\
Kuriki et al., 2002 & $130-150 \mathrm{mg} /$ day \\
\hline
\end{tabular}

and the role of neuro-inflammation, we will present recent data about ARA contribution to AD mechanisms including ours. On this basis, we will propose some hypothesis on the ARAassociated mechanisms in $\mathrm{AD}$.

\section{Arachidonic acid in the current western diets}

Several studies were performed in the 1990s to evaluate the ARA daily intake in the western diets and its main sources in food. According to these studies, ARA daily intakes are in a wide range from 100 to $200 \mathrm{mg} /$ day (Jonnalagadda et al., 1995; Mann et al., 1995). Studies on Japanese population reported a narrower but compatible range of values between 100 and $200 \mathrm{mg} /$ day (Tokudome et al., 1999; Kuriki et al., 2002). This wide range of daily intakes (see Tab. 1 for comparison of the various studies) in western diets could make difficult the determination of ARA contents in currently consumed foods as suggested by some works about the ARA underestimation at least in American diet (Taber et al., 1998). ARA is provided directly from some food components such as red meat, chicken, eggs but also fish (http://appliedresearch.cancer.gov/ diet/foodsources/fattyacids/table4.html, data from the National Health and Nutrition Examination Survey 2005-2006 USA). For example, a recent study established that ARA plasma concentration is associated with the consumption of red meat in the Singapore Chinese population (Seah et al., 2017). Although membrane phospholipids are frequently considered as the main source of ARA, Li et al. (1998) reported that meat fat and triglycerides provide similar or even higher ARA amounts especially in white meat, chicken or pork. The case of chicken or other poultry has to be considered since they are frequently consumed in many countries and higher ARA content in poultry improve the taste of the meat (Kiyohara et al., 2011; Takahashi et al., 2012). Methods of raising and feeding poultries could therefore increase dietary ARA intakes in humans.

ARA also results from the conversion of its precursor linoleic acid [LNA], i.e. the elongation by elongases and desaturation by $\Delta$ and $\Delta 6$ desaturases. LNA is much more abundant in human food than ARA. The European Food Safety Authority [EFSA]) recommended in 2009 the consumption of $2 \mathrm{~g} /$ day of $\alpha$-linolenic acid and $10 \mathrm{~g}$ /day of LNA (European Food Safety Authority, 2009) which corresponded to an increase of the previous recommendations for $\omega-3$ and $\omega-6$ daily intakes ( $2 \mathrm{~g} /$ day and $6 \mathrm{~g} /$ day respectively in 1992). In parallel, the World Health Organization recommended that $0.5-2 \%$ and $2.5-5 \%$ of energy should be provided by $\omega-3$ and 
Tau - dependent pathway

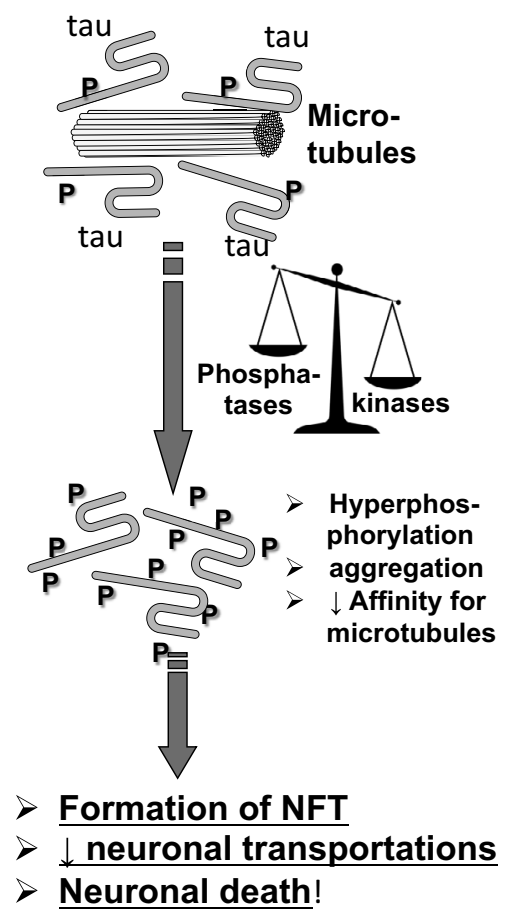

$A \beta$ peptide - dependent pathway

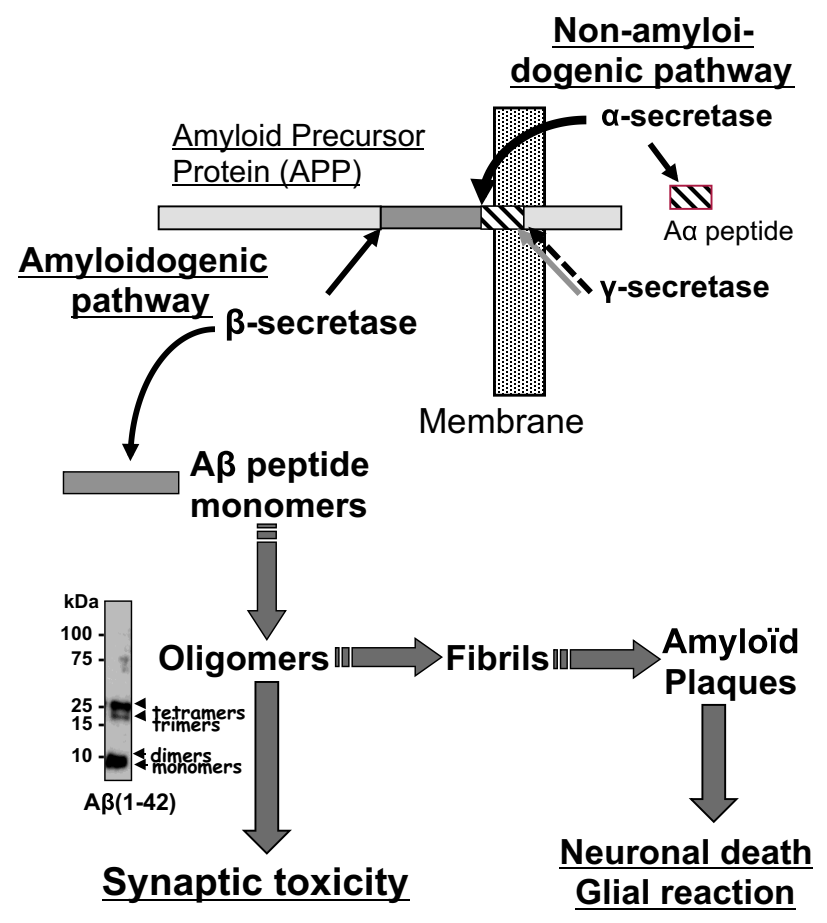

Fig. 1. Roles of tau and $A \beta$ oligomers in AD. The tau-dependent pathway is associated to hyperphorylation and aggregation of tau-proteins inducing alterations of neuronal transportations and finally, neuronal death. The $A \beta$ peptide-dependent pathway is associated to $A \beta$ peptide production and toxic oligomer formation which alter synaptic functions. In a final step, A $\beta$ peptide oligomers aggregate into amyloid plaques from oligomers which contribute to glial reaction and neuronal death.

$\omega-6$ PUFAs, respectively (i. e. 1.5-6 g/day and 7.5-15 g/day of $\omega-3$ and $\omega-6$ PUFAs, respectively) (FAO/WHO, 2008). In France, the National Individual study on Alimentary Consumptions [INCA] showed that the French people eat on average $9 \mathrm{~g}$ /day of LNA $(\omega-6)$ and $0.9 \mathrm{~g} /$ day of linolenic acid $(\omega-3)$ while the US daily average intakes are $18 \mathrm{~g}$ and $2 \mathrm{~g}$ of LNA and linolenic acid, respectively, according the 2012 USDA study (USDA, 2012). A few studies investigated the rate of conversion of consumed LNA into ARA in adults and their data indicated that this conversion poorly contributes to the ARA amounts found in plasma or in liver (Adam et al., 2008). On the contrary, the brain ARA requirement of the fetal baboon are met by dietary maternal LNA (Su et al., 1999), which suggest that the brain development period must be considered separately from what happen in adult organism. Additional worldwide studies are needed to provide more precise evaluation of the daily ARA intake, the LNA contribution to the ARA amounts found in peripheral organs as well in brain and the main food sources of ARA.

\section{Main molecular actors of Alzheimer's disease and contribution of neuro- inflammation}

AD was originally defined in 1906 by Aloïs Alzheimer by the presence of two histological pathognomonic signs in brain of affected patients:
- neurofibrillary tangles (NFTs);

- amyloid plaques (Berrios, 1990).

Neurofibrillary tangles are formed by aggregation of hyperphosphorylated tau protein filaments while amyloid plaques result from aggregation of amyloid- $\beta[A \beta]$ peptide (Fig. 1). Tau protein physiologically associates to microtubules in mature neurons and play an important role in neuronal signalling and axonal transport (Nisbet et al., 2015; Chong et al., 2018). Hyperphosphorylation of tau in AD probably result from a disequilibrium between kinase (CDK5, GSK3 $\beta$, ERK2 and/or other still unidentified kinases) and phosphatase activities (Gong et al., 2000) and facilitate the formation of tau helical filaments which finally aggregate into NFTs. In addition, hyperphosphorylation of tau decrease its affinity for microtubules which drastically alters the axonal transportations (Iqbal et al., 1994). The importance of tau dysregulation is highlighted by the correlation between the clinical symptoms and the extension of NFTs through the various brain regions (the entorhinal cortex in the earliest steps, then in the limbic system and the hippocampus the neocortex in the latest stages of AD) (Silverman et al., 1997).

The amyloid plaques are formed by aggregates of amyloid$\beta[A \beta]$ peptide. The $A \beta$ peptide is produced by the amyloidogenic cleavage of the transmembrane amyloid precursor protein [APP] which function is still unknown. In this amyloidogenic way, the N-terminal portion of APP is 
cleaved by the major $\beta$-secretase BACE1 while the $\mathrm{C}$-terminal portion of APP is cleaved by the $\gamma$-secretase, both the cleavage releasing the $A \beta$ peptide and two other $\mathrm{N}$-terminal (sAPP $\beta$ ) and C-terminal (AICD) fragments (Vassar et al., 1999). There are two major forms of $A \beta$ peptide: $A \beta_{1-40}$, which is the most abundant form $(90 \%)$ and $A \beta_{1-42}(10 \%)$, which is the most toxic form. Since the clinical symptoms are not correlated with the number and size of the amyloid plaques (Lue et al., 1999), many authors concluded in the early 2000s that amyloid plaques is not the engine of the pathological process but a late symptoms. They postulated that the $A \beta$ oligomers, formed by the $A \beta$ peptides before their fibrillization and deposition into plaques, are the initial agent of AD. This hypothesis is presently largely recognized since numerous studies demonstrated that these $A \beta$ oligomers induce early synaptotoxicity and damages to neuronal networks, leading to memory impairment (Gong et al., 2003; Lacor et al., 2007; Shankar et al., 2008). Despite numerous works, the relationship between tau and $A \beta$ peptide oligomers is still poorly known. Several studies established that the pathological effects induced by the $A \beta$ peptide oligomers required the presence of intact tau (Vossel et al., 2010; Mairet-Coello et al., 2013). Although it is still a subject of debate, A $\beta$ peptide oligomers appear as the earliest and more specific AD agents since tau alterations are observed in many other neurodegenerative diseases (Lebouvier et al., 2017).

One of the main question emerging from the tremendous numbers works on $\mathrm{AD}$ and $\mathrm{A} \beta$ peptide oligomers is the root cause of intracerebral accumulation of these oligomers in AD since there is no clear evidence of $A \beta$ peptide overproduction in sporadic $\mathrm{AD}$ cases $(>99 \%$ of the $\mathrm{AD}$ cases) on the contrary to the genetic cases $<1 \%$ of the cases). Dysregulations of neuro-inflammatory processes could at least contribute to this accumulation. The importance of neuroinflammation in $\mathrm{AD}$ is supported by the findings of associations between AD and genes coding for immune receptors, such as TREM2 (Guerreiro et al., 2013) and CD33 (Griciuc et al., 2013). Microglial cells, which are major actors in neuroinflammation with astrocytes, recognize $A \beta$ peptide oligomers through the binding to the cell-surface toll like receptors (Walter et al., 2007; Liu et al., 2012). Stewart et al. described that TLR-4 and -6 form heterodimers able to bind $A \beta$ peptide as well as oxidized LDL and associate with CD36 to generate cytokine production and inflammation (Stewart et al., 2010). Why microglial or astroglial cells are unable to eliminate $A \beta$ peptide and impede accumulation of $A \beta$ oligomers and plaque formations is still unknown. Whether neuroinflammation is just reactive to the presence of undesirable $A \beta$ peptide oligomers or whether an active contributor to AD pathological processes is also an opened question. But many recent data highlighted neuroinflammation as an important actor and a therapeutic target against AD (Ardura-Fabregat et al., 2017).

\section{Arachidonic acid in brain functions and Alzheimer's disease: an essential lipid or a pathological agent?}

ARA is usually considered as an essential fatty acid especially for brain development in association with DHA. To date, few studies provided some evidenced to support this hypothesis. Since ARA and its precursor LNA are very abundant in human food and maternal milk, no drastic deficiency has been described on the contrary to DHA, which is 10-20-fold less abundant. Some studies in humans or in primates indicated that blood ARA levels are not influenced by diet on the contrary to DHA in humans (Ghebremeskel et al., 2000; Diau et al., 2005; Lauritzen et al., 2015) and suggested that DHA/ARA ratio is strictly maintained (Ghebremeskel et al., 2000). However, a slower growth has been observed in case of low ARA levels (Ghebremeskel et al., 2000). Several studies performed on rodents indicated that maternal ARA supplementation could compensate the alterations of cognitive abilities in pups induced by maternal metabolic diseases such as streptozotocin-induced diabetes (Zhao et al., 2011) and diet/ APO-E* 3 leiden genotype-induced obesity (Arnoldussen et al., 2016). A decrease of obesity was observed in the APO-E* 3 leiden adult mice with a combination of ARA and DHA supplementation but not with DHA alone (Wielinga et al., 2012). Studies on $\Delta 6$ desaturase knockout mice showed that supplementation with both DHA and ARA are necessary to compensate the PUFAs deficiencies in brain and the effects on motor activity and coordination during development (Hatanaka et al., 2016; Harauma et al., 2017). But, long-term administration of ARA in adult mice maintained under $\omega-3$ deficient diet increases the severity of motor coordination alterations indicating that preservation of adequate DHA intake are necessary in any case (Harauma et al., 2015). It is important to emphasize that sex should be considered for these studies about dietary lipid intake and brain functions since brain lipid composition and diet influence differ in male and female mice (Rodriguez-Navas et al., 2016).

Higher dietary ARA intakes or ARA diet supplementation counteract the reduction of cognition and synaptic activity which are observed in healthy aged rodents (McGahon et al., 1997; McGahon et al., 1998; Kotani et al., 2003; Okaichi et al., 2005). An ARA positive effect has also been reported on neurogenesis in rodent hippocampus (Tokuda et al., 2014) but it is difficult to transpose these data in humans whose neurogenesis is weak especially during aging. On the contrary, we observed a negative influence of dietary ARA in a murine $\mathrm{AD}$ model. We previously showed that $\mathrm{A} \beta$ oligomers activate, in neuronal cells, cytosolic phospholipase $\mathrm{A}_{2}\left(\mathrm{cPLA}_{2}\right)$ which specifically releases ARA from membrane phospholipids (Kriem et al., 2005). We then showed that cognitive abilities and expression of the synaptic proteins PSD95 and SNAP25 are preserved in $\mathrm{CPLA}_{2}{ }^{-1-}$ mice after an intracerebroventricular injection (ICV) of $\mathrm{A} \beta$ oligomers while they are drastically altered in wild-type mice after this treatment (Desbène et al., 2012). By breeding $\mathrm{cPLA}_{2}{ }^{-/-}$mice and transgenic AD model mice overproducing $\mathrm{A} \beta$ peptide, Sanchez-Mejia et al. (2008) also showed that the reduction of $\mathrm{cPLA}_{2}$ reduce the neurotoxicity of $\mathrm{A} \beta$ peptides. Since $\mathrm{cPLA}_{2}$ specifically hydrolyze ARA containing phospholipids, we assumed that higher dietary ARA intakes could lead to higher ARA brain incorporation and favor its release by $A \beta$ peptide oligomer-activated $\mathrm{cPLA}_{2}$. Therefore, we studied the effects of a single ICV of A $\beta$ peptide oligomers in mice fed with a $1 \%$ ARA containing diet for 12 weeks (Thomas et al., 2017). We also used a control diet in which oleic acid replaced ARA (see Fig. 2 for the experimental layout of this study). Both ARA-rich and control diets contained adequate amounts 


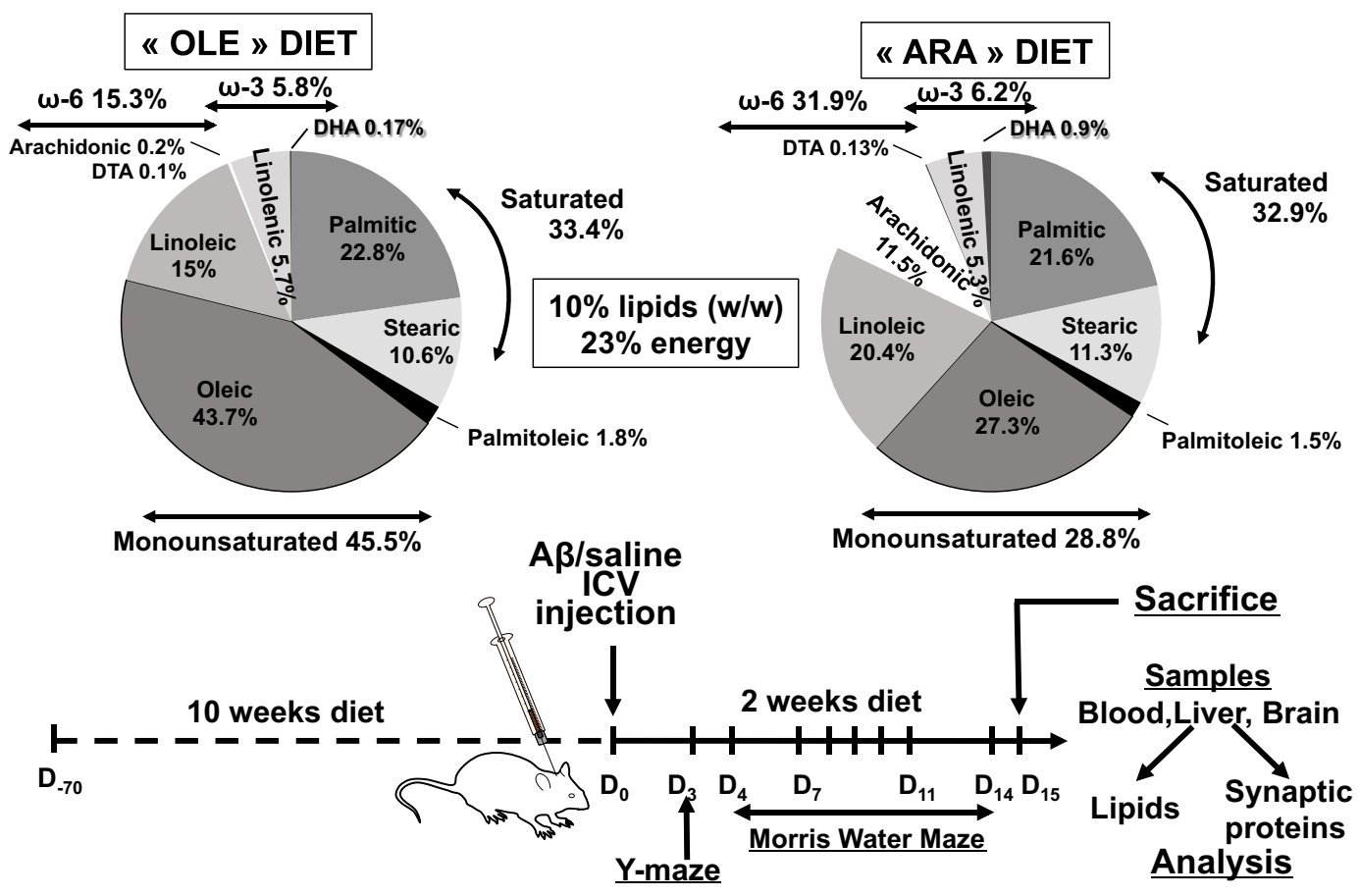

Fig. 2. Experimental layout of Thomas et al. (2017) study. In this study, two groups groups of mice were fed for 12 weeks either with an oleic acid rich diet (control OLE diet) or an ARA-rich diet (ARA diet). The two diets contained similar amounts of saturated and $\omega-3$ fatty acids. In the OLE diet, oleic acid replace the excess of $\omega-6$ fatty acids (mainly ARA). At week 10, the two groups of mice were submitted to intracerebroventricular injections of $\mathrm{A} \beta(1-42)$ peptide oligomers or saline solution (control). Congitive abilities were measured by using the Ymaze (short term memory) and the Moorris Water maze (long term memory) tests. Mice were sacrificed at the end of week 12 and blood, liver and brain samples were collected for protein (synaptic proteins in brain) and lipid analyses.

of DHA and linolenic acid for murine needs. We observed a drastic reduction of learning abilities, reduction of AMPA receptor expression levels and increase of the astrocytic marker GFAP expression after $A \beta$ peptide oligomer ICV in mice fed with the ARA-rich diet compared to the control group. These negative effects of dietary ARA are consistent with those of Amtul et al. (2012) who reported that a 2\% ARA containing diets increased of $A \beta_{1-42}$ production and deposition in transgenic AD-model CRND8 mice after 21 weeks. By contrast, Hosono et al. (2015a, 2015b) described an improvement of cognitive alterations and a reduction of amyloid plaques by supplementation with ARA in 17-monthold Tg2576 mice. The authors did not observe the same positive results with DHA supplementation. But in this transgenic AD-model, the $\mathrm{A} \beta$ peptide overproduction due to mutant human APP overexpression leads to massive amyloid deposition and drastic alterations of cognitive abilities before the age of 12 months. In the early step of sporadic AD, there is no evidence of $A \beta$ peptide overproduction and memory alterations are not caused by amyloid plaque formation but to the synaptotoxicity of $A \beta$ oligomers. Our single $A \beta$ oligomer ICV model is supposed to reproduce this early synaptoxicity (Youssef et al., 2008). The two groups (Hosono et al., 2015a, 2015b; Amtul et al., 2012) who studied the effects of dietary ARA did not show any result about the modification of brain lipids and/or ARA brain incorporation. In our study, we measure reproducible but small increase of ARA levels in ARA diet-fed mice. This minor increase compared to the large modifications that we observed in blood and liver, do not support the existence of a drastic release of free ARA in brain and its direct influence on brain inflammation or synaptic functions. Dietary ARA could increase the brain sensitivity to $\mathrm{A} \beta$ oligomer toxicity through the transmission of inflammatory signals from the peripheral compartment to brain (see Tab. 2 for the comparison of the studies on the role of dietary ARA).

\section{Dietary arachidonic acid: an actor of chronic sub-inflammation from gut to brain?}

The role of acute or chronic systemic inflammation in the $\mathrm{AD}$ progression emerged quite recently in literature and was initially focused on the circulation of pro-inflammatory cytokines (Holmes et al., 2009) The usually admitted dogma that increased ARA levels increase eicosanoid production was supported by some works (Whelan et al., 1993; Whelan et al., 1997) but this eicosanoid production is not automatically associated to cytokine secretion (Kelley et al., 1997). Dietary ARA has been mainly involved in two chronic pathologies in which inflammation plays a critical role: bowel disease and obesity. Conversion of arachidonic acid into pro-inflammatory leukotriene was early recognized as a key event in Bowel disease (Nielsen et al., 1987). But more recent works indicated that dietary ARA is rather protective against colitis progression (Ramakers et al., 2008; Knoch et al., 2010). ARA might favour obesity by acting on the differentiation of brite adipocytes which are energy-dissipating cells (Pisani et al., 2014). In addition, ARA impairs hypothalamic leptin signal, thus 
Table 2. Experimental features and main data of the previous studies on the role of arachidonic acid in AD. We previously showed the mice in which the expression of the main ARA releasing enzyme $\mathrm{CPLA}_{2}$ has been suppressed, are resistant to the neurotoxicity of the $\mathrm{A} \beta$ peptide oligomers. By contrast, an ARA-rich diet increase the sensitivity of the mice to the neurotoxicity of the A $\beta$ peptide oligomers. Two other teams studied the role of dietary ARA and reported conflicting results.

\begin{tabular}{|c|c|c|}
\hline Sources & Main experimental features & Main experimental data \\
\hline \multirow{2}{*}{ Thomas et al., 2017} & $1 \%$ ARA diet for 12 weeks & $\searrow$ AMPA Receptors \\
\hline & ICV injection of $A \beta$ peptides & $\nearrow \mathrm{GFAP}$ \\
\hline Amtul et al., 2012 & CRND8 mice & $\nearrow \mathrm{A} \beta_{1-42}$ production and deposition \\
\hline Hosono et al., 2015a, 2015b & ARA Supplementation of the diet $4 \%$ & $\searrow$ Amyloid plaques \\
\hline
\end{tabular}

promoting obesity (Cheng et al., 2015). However, there is still a debate about the ARA influence on obesity-associated inflammation (Suitor et al., 2017). The role of intestinal microbiota should be considered to reconcile the various data on dietary ARA effects on systemic chronic sub-inflammation in obesity, Bowel disease or chronic pathologies proinflammatory. For example, Zhuang et al. (2017) recently showed that dietary ARA favour obesity and by acting on the hypothalamus-liver-adipocytes axis but the effect is modulated by sex and intestinal microbiota, female mice being less pejoratively affected. This result should be related to the current work on the relationship between the gut microbiota and Alzheimer's disease (for review see Jiang et al., 2017). Therefore, the role of gut microbiota, gut-brain communications, systemic inflammation and its transmission to brain through the blood-brain barrier should be further investigated to design preventive strategies against AD (Fig. 3).

\section{Conclusion}

AD prevention is a critical challenge to stop the increasing AD prevalence worldwide. Nutrition is one of the main tools in preventive strategies, but risk factor must be more precisely characterized. On this point of view, ARA contribution to western diet and AD risk should be more extensively studied. Several preclinical works including ours suggest that ARA could favour AD occurrence and progression although other studies indicated that ARA could play a positive role in physiological aging. Additional studies are required on the various mechanisms induced by high dietary intakes including modulation of inflammation, modification of the gut microbiota, influence on the gut-blood and blood-brain barriers. It is noticeable that a correlation between ARA and cholesterol consumption and higher risk of occurrence of Parkinson's disease has been reported in the japan population (Miyake et al., 2010) which suggest that dietary ARA could be a target in preventive strategies against other neurodegenerative diseases.

Acknowledgements. We thank the France-Alzheimer association and the Region Loraine for their financial support to the works performed by the group and presented in this review.

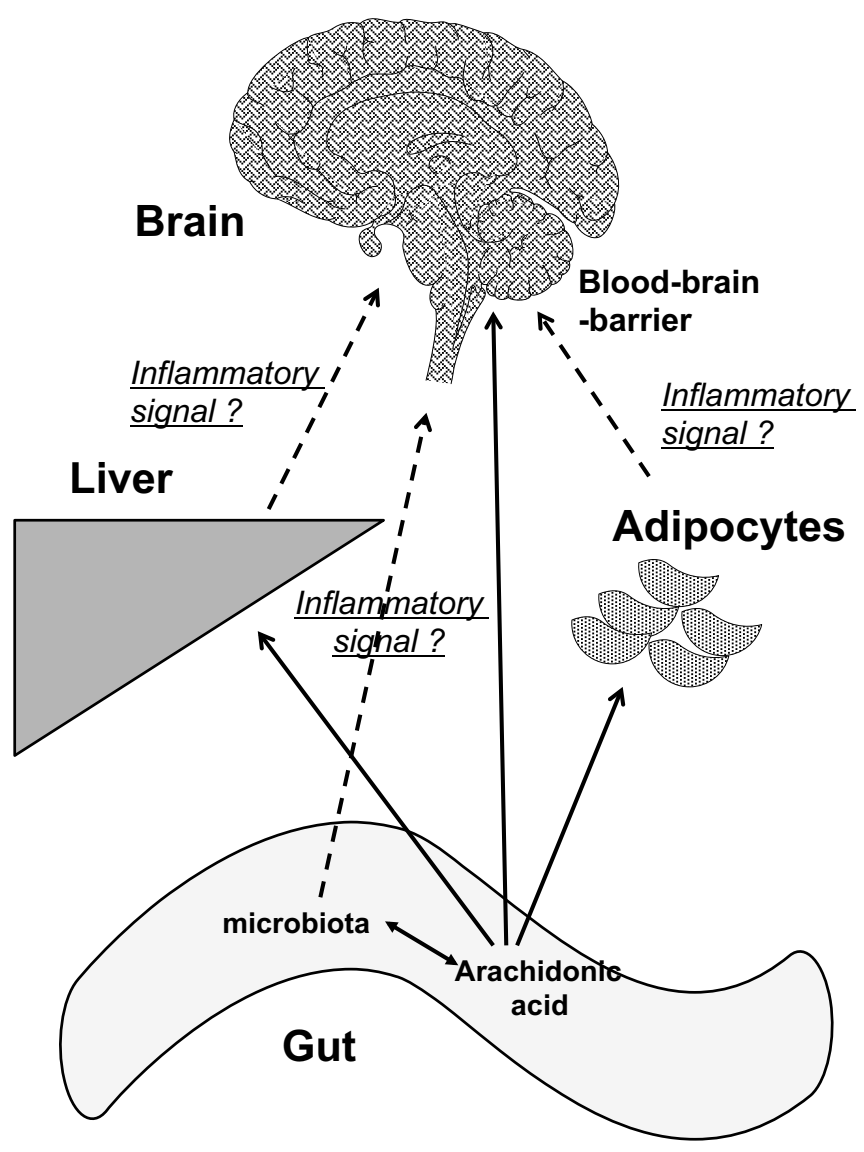

Fig. 3. Putative roles of gut-brain communications, gut microbiota and systemic inflammation in the dietary arachidonic acid effects on the sensitivity to the $A \beta$ peptide oligomer neurotoxicity. ARA has an impact directly or indirectly on the brain. An ARA-rich diet can modify the composition of intestinal microbiota to induce inflammatory mediators and thus, have effects on the $A \beta$ peptide oligomer neurotoxicity. Indeed, arachidonic acid can affect the brain by going liver, adipocytes and inflammatory mediators.

Conflicts of interest. The authors declare that they have no conflicts of interest in relation to this article. 


\section{References}

Adam O, Tesche A, Wolfram G. 2008. Impact of linoleic acid intake on arachidonic acid formation and eicosanoid biosynthesis in humans. Prostaglandins Leukot Essent Fatty Acids 79: 177-181.

Amtul Z, Uhrig M, Wang L, Rozmahel RF, Beyreuther K. 2012. Detrimental effects of arachidonic acid and its metabolites in cellular and mouse models of Alzheimer's disease: structural insight. Neurobiol Aging 33: 831.e21-831.e31.

Ardura-Fabregat A, Boddeke EWGM, Boza-Serrano A, et al. 2017. Targeting neuroinflammation to treat Alzheimer's disease. CNS Drugs 31: 1057-1082.

Arnoldussen IA, Zerbi V, Wiesmann M, et al. 2016. Early intake of long-chain polyunsaturated fatty acids preserves brain structure and function in diet-induced obesity. J Nutr Biochem 30: 177188.

Berrios GE. 1990. Alzheimer's disease: a conceptual history. Int J Ger Psychiatry 5: 355-365.

Cheng L, Yu Y, Zhang Q, Szabo A, Wang H, Huang XF. 2015. Arachidonic acid impairs hypothalamic leptin signaling and hepatic energy homeostasis in mice. Mol Cell Endocrinol 412: $12-18$.

Chong FP, Ng KY, Koh RY, Chye SM. 2018. Tau proteins and tauopathies in Alzheimer's disease. Cell Mol Neurobiol, in press.

Desbène C, Malaplate-Armand C, Youssef I, et al. 2012. Critical role of cPLA2 in A $\beta$ oligomer-induced neurodegeneration and memory deficit. Neurobiol Aging 33: 1123.e17-1123.e29.

Diau GY, Hsieh AT, Sarkadi-Nagy EA, Wijendran V, Nathanielsz PW, Brenna JT. 2005. The influence of long chain polyunsaturated fatty acid supplementation on docosahexaenoic acid and arachidonic acid in baboon neonate central nervous system. BMC Med 3: 11.

European Food Safety Authority. 2009. Scientific opinion: labelling reference intake values for $n-3$ and $n-6$ polyunsaturated fatty acids. EFSA $J$ 1176: 1-11.

FAO/WHO. 2008. Interim summary of conclusions and dietary recommendations on total fat $\&$ fatty acids, in expert consultation on fats and fatty acids in human. Geneva, pp. 10-14.

Ghebremeskel K, Crawford MA, Lowy C, et al. 2000. Arachidonic and docosahexaenoic acids are strongly associated in maternal and neonatal blood. Eur J Clin Nutr 54: 50-56.

Gong CX, Lidsky T, Wegiel J, Zuck L, Grundke-Iqbal I, Iqbal K. 2000. Phosphorylation of microtubule-associated protein tau is regulated by protein phosphatase $2 \mathrm{~A}$ in mammalian brain. Implications for neurofibrillary degeneration in Alzheimer's disease. J Biol Chem 275: 5535-5544.

Gong Y, Chang L, Viola KL, et al. 2003. Alzheimer's disease-affected brain: presence of oligomeric A beta ligands (ADDLs) suggests a molecular basis for reversible memory loss. Proc Natl Acad Sci U $S$ A 100: 10417-10422.

Griciuc A, Serrano-Pozo A, Parrado AR, et al. 2013. Alzheimer's disease risk gene CD33 inhibits microglial uptake of amyloid beta. Neuron 78: 631-643.

Guerreiro R, Wojtas A, Bras J, 2013. et al. TREM2 variants in Alzheimer's disease. $N$ Engl J Med 368: 117-127.

Harauma A, Tomita M, Muto D, Moriguchi T. 2015. Effect of longterm administration of arachidonic acid on n-3 fatty acid deficient mice. Prostaglandins Leukot Essent Fatty Acids 95: 41-45.

Harauma A, Yasuda H, Hatanaka E, Nakamura MT, Salem N Jr, Moriguchi T. 2017. The essentiality of arachidonic acid in addition to docosahexaenoic acid for brain growth and function. Prostaglandins Leukot Essent Fatty Acids 116: 9-18.
Hatanaka E, Harauma A, Yasuda H, et al. 2016. Essentiality of arachidonic acid intake in murine early development. Prostaglandins Leukot Essent Fatty Acids 108: 51-57.

Holmes C, Cunningham C, Zotova E, et al. 2009. Systemic inflammation and disease progression in Alzheimer disease. Neurology 73: 768-774.

Hosono T, Mouri A, Nishitsuji K, et al. 2015a. Arachidonic or docosahexaenoic acid diet prevents memory impairment in Tg2576 Mice. J Alzheimers Dis 48: 149-162.

Hosono T, Nishitsuji K, Nakamura T, et al. 2015b. Arachidonic acid diet attenuates brain $\mathrm{A} \beta$ deposition in Tg2576 mice. Brain Res 1613: 92-99.

INCA 2. Étude Individuelle Nationale sur les Consommations Alimentaires. 2006-2007.

Iqbal K, Alonso AC, Gong CX, Khatoon S, Singh TJ, Grundke-Iqbal I. 1994. Mechanism of neurofibrillary degeneration in Alzheimer's disease. Mol Neurobiol 9: 119-123.

Jiang C, Li G, Huang P, Liu Z, Zhao B. 2017. The Gut Microbiota and Alzheimer's Disease. J Alzheimers Dis 58: 1-15.

Jonnalagadda SS, Egan SK, Heimbach JT, Harris SS, Kris-Etherton PM. 1995. Fatty acid consumption paterns of Americans: 1987 1988 SDA Nationwide Food Consumption Survey. Nutr Res 15: 1767-1781.

Kelley DS, Taylor PC, Nelson GJ, Schmidt PC, Mackey BE, Kyle D. 1997. Effects of dietary arachidonic acid on human immune response. Lipids 32: 449-456.

Kiyohara R, Yamaguchi S, Rikimaru K, Takahashi H. 2011. Supplemental arachidonic acid-enriched oil improves the taste of thigh meat of Hinai-jidori chickens. Poult Sci 90: 1817-1822.

Knoch B, Barnett MP, McNabb WC, et al. 2010. Dietary arachidonic acid-mediated effects on colon inflammation using transcriptome analysis. Mol Nutr Food Res 54(Suppl. 1): S62-S74.

Kotani S, Nakazawa H, Tokimasa T, et al. 2003. Synaptic plasticity preserved with arachidonic acid diet in aged rats. Neurosci Res 46: 453-461.

Kriem B, Sponne I, Fifre A, et al. 2005. Cytosolic phospholipase $\mathrm{A}_{2}$ mediates neuronal apoptosis induced by soluble oligomers of the amyloid-beta peptide. FASEB J 19: 85-87.

Kuriki K, Nagaa T, Imaeda N, et al. 2002. Discrepancies in dietary intakes and plasma concentrations of fatty acids according to age among Japanese female dietitians. Eur J Clin 56: 524-531.

Lacor PN, Buniel MC, Furlow PW, et al. 2007. Abeta oligomerinduced aberrations in synapse composition, shape, and density provide a molecular basis for loss of connectivity in Alzheimer's disease. J Neurosci 27: 796-807.

Lauritzen L, Fewtrell M, Agostoni C. 2015. Dietary arachidonic acid in perinatal nutrition: a commentary. Pediatr Res 77: 263-269.

Lebouvier T, Pasquier F, Buée L. 2017. Update on tauopathies. Curr Opin Neurol 30: 589-598.

Li D, Ng A, Mann NJ, Sinclair AJ. 1998. Contribution of meat fat to dietary arachidonic acid. Lipids 33: 437-440.

Liu S, Liu Y, Hao W, et al. 2012. TLR2 is a primary receptor for Alzheimer's amyloid $\beta$ peptide to trigger neuroinflammatory activation. J Immunol 188: 1098-1107.

Lue L, Kuo YM, Roher AE, et al. 1999. Soluble amyloid beta peptide concentration as a predictor of synaptic change in Alzheimer's disease. Am J Pathol 155: 853-862.

Mairet-Coello G, Courchet J, Pieraut S, et al. 2013. The CAMKK2AMPK kinase pathway mediates the synaptotoxic effects of $\mathrm{A} \beta$ oligomers through Tau phosphorylation. Neuron 78: 94-108.

Mann NJ, Johnson LG, Warrick GE, Sinclair AJ. 1995. The arachidonic acid content of the Australian diet is lower than previously estimated. $J$ Nutr 125 : 2528-2535. 
McGahon B, Clements MP, Lynch MA. 1997. The ability of aged rats to sustain long-term potentiation is restored when the age-related decrease in membrane arachidonic acid concentration is reversed. Neuroscience 81: 9-16.

McGahon B, Murray CA, Clements MP, Lynch MA. 1998. Analysis of the effect of membrane arachidonic acid concentration on modulation of glutamate release by interleukin-1: an age-related study. Exp Gerontol 33: 343-354.

Miyake Y, Sasaki S, Tanaka K, et al. 2010. Dietary fat intake and risk of Parkinson's disease: a case-control study in Japan. J Neurol Sci 288: $117-122$.

Nielsen OH, Ahnfelt-Rønne I, Elmgreen J. 1987. Abnormal metabolism of arachidonic acid in chronic inflammatory bowel disease: enhanced release of leucotriene B4 from activated neutrophils. Gut 28: 181-185.

Nisbet RM, Polanco JC, Ittner LM, Götz J. 2015. Tau aggregation and its interplay with amyloid- $\beta$. Acta Neuropathol 129: 207-220.

Nishizaki T, Nomura T, Matsuoka T, Tsujishita Y. 1992. Arachidonic acid as a messenger for the expression of long-term potentiation. Biochem Biophys Res Commun 254: 446-449.

Okaichi Y, Ishikura Y, Akimoto K, et al. 2005. Arachidonic acid improves aged rats' spatial cognition. Physiol Behav 84: 617-623.

Pisani DF, Ghandour RA, Beranger GE, et al. 2014. The $\omega 6$-fatty acid, arachidonic acid, regulates the conversion of white to brite adipocyte through a prostaglandin/calcium mediated pathway. Mol Metab 3: 834-847.

Ramakers JD, Mensink RP, Verstege MI, te Velde AA, Plat J. 2008. An arachidonic acid-enriched diet does not result in more colonic inflammation as compared with fish oil- or oleic acid-enriched diets in mice with experimental colitis. Br J Nutr 100: 347-554.

Rickman C, Davletov B. 2005. Arachidonic acid allows SNARE complex formation in the presence of Munc18. Chem Biol 12: 545-553.

Rodriguez-Navas C, Morselli E, Clegg DJ. 2016. Sexually dimorphic brain fatty acid composition in low and high fat diet-fed mice. $\mathrm{Mol}$ Metab 5: 680-689.

Sanchez-Mejia RO, Newman JW, Toh S, et al. 2008. Phospholipase $\mathrm{A}_{2}$ reduction ameliorates cognitive deficits in a mouse model of Alzheimer's disease. Nat Neurosci 11: 1311-1318.

Seah JY, Gay GM, Su J, et al. 2017. Consumption of red meat, but not cooking oils high in polyunsaturated fat, is associated with higher arachidonic acid status in Singapore Chinese adults. Nutrients 9. pii: E101.

Shankar GM, Li S, Mehta TH, et al. 2008. Amyloid-beta protein dimers isolated directly from Alzheimer's brains impair synaptic plasticity and memory. Nat Med 14: 837-842.

Silverman W, Wisniewski HM, Bobinski M, Wegiel J. 1997. Frequency of stages of Alzheimer-related lesions in different age categories. Neurobiol Aging 18: 389-392.

Stewart CR, Stuart LM, Wilkinson K, et al. 2010. CD36 ligands promote sterile inflammation through assembly of a toll-like receptor 4 and 6 heterodimer. Nat Immunol 11: 155-161.

Su HM, Corso TN, Nathanielsz PW, Brenna JT. 1999. Linoleic acid kinetics and conversion to arachidonic acid in the pregnant and fetal baboon. J Lipid Res 40: 1304-1312.
Suitor K, Payne GW, Sarr O, et al. 2017. Arachidonic acid promote white adipose tissue inflammation in Fads2-/- mice fed low fat diets. Prostaglandins Leukot Essent Fatty Acids 126: 84-91.

Taber L, Chiu CH, Whelan J. 1998. Assessment of the arachidonic acid content in foods commonly consumed in the American diet. Lipids 33: 1151-1157.

Takahashi H, Rikimaru K, Kiyohara R, Yamaguchi S. 2012. Effect of arachidonic acid-enriched oil diet supplementation on the taste of broiler meat. Asian-Australas J Anim Sci 25: 845-851.

Thomas MH, Paris C, Magnien M, et al. 2017. Dietary arachidonic acid increases deleterious effects of amyloid- $\beta$ oligomers on learning abilities and expression of AMPA receptors: putative role of the ACSL4-cPLA 2 balance. Alzheimers Res Ther 9: 69.

Tokuda H, Kontani M, Kawashima H, Kiso Y, Shibata H, Osumi N. 2014. Differential effect of arachidonic acid and docosahexaenoic acid on age-related decreases in hippocampal neurogenesis. Neurosci Res 88: 58-66.

Tokudome Y, Imaeda N, Ikeda M, Kitagawa I, Fujiwara N, Tokudome S. 1999. Foods contributing to absolute intake and variance in intake of fat, fatty acids, and cholesterol in middle-aged Japanese. $J$ Epidemiol 9: 78-90.

USDA nutrient intakes from food: mean amounts consumed per individual, by gender and age. 2012. What we eat in America, NHANES 2009-2010. USDA, Agricultural Research Service.

Vassar R, Bennett BD, Babu-Khan S, et al. 1999. Beta-secretase cleavage of Alzheimer's amyloid precursor protein by the transmembrane aspartic protease BACE. Science 286: 735-741.

Vossel KA, Zhang K, Brodbeck J, et al. 2010. Tau reduction prevents Abeta-induced defects in axonal transport. Science 330: 198.

Walter S, Letiembre M, Liu Y, et al. 2007. Role of the toll-like receptor 4 in neuroinflammation in Alzheimer's disease. Cell Physiol Biochem 20: 947-956.

Whelan J, Li B, Birdwell C. 1997. Dietary arachidonic acid increases eicosanoid production in the presence of equal amounts of dietary eicosapentaenoic acid. Adv Exp Med Biol 400B: 897-904.

Whelan J, Surette ME, Hardardóttir I, et al. 1993. Dietary arachidonate enhances tissue arachidonate levels and eicosanoid production in Syrian hamsters. J Nutr 123: 2174-2185.

Wielinga PY, Harthoorn LF, Verschuren L, et al. 2012. Arachidonic acid/docosahexaenoic acid-supplemented diet in early life reduces body weight gain, plasma lipids, and adiposity in later life in ApoE*3Leiden mice. Mol Nutr Food Res 56: 1081-1089.

Youssef I, Florent-Béchard S, Malaplate-Armand C, et al. 2008. Ntruncated amyloid-beta oligomers induce learning impairment and neuronal apoptosis. Neurobiol Aging 29: 1319-1333.

Zhao J, Del Bigio MR, Weiler HA. 2011. Maternal arachidonic acid supplementation improves neurodevelopment in young adult offspring from rat dams with and without diabetes. Prostaglandins Leukot Essent Fatty Acids 84: 63-70.

Zhuang P, Shou Q, Lu Y, et al. 2017. Arachidonic acid sexdependently affects obesity through linking gut microbiota-driven inflammation to hypothalamus-adipose-liver axis. Biochim Biophys Acta 1863: 2715-2726.

Cite this article as: Pinchaud K, Maguin-Gaté K, Olivier J-L. 2018. Dietary arachidonic acid: a Janus face actor in brain and Alzheimer's disease? OCL 25(4): D406. 